\title{
The role of vacancies and local distortions in the design of new phase-change materials
}

MATTHIAS WUTTIG, DANIEL LÜSEBRINK, DANIEL WAMWANGI, WOJCIECH WEENIC, MICHAEL GILLEßEN AND RICHARD DRONSKOWSKI

This issue, pp. 122-128; Published online 17 December 2006; doi:10.1038/nmat1807

The authors wish to cite an extra reference to adjoin reference 19:

Dronskowski, R. \& Blöchl, P. E. Crystal orbital Hamilton populations (COHP): energy-resolved visualization of chemical bonding in solids based on density-functional calculations. J. Phys. Chem. 97, 8617-8624 (1993). 